\title{
Applying Augmented Reality-Based Fun Book Technology (Round Table Learning Media) for Teaching-Learning of Coastal Community
}

\author{
Muhammad Bayu Purnama1, Zayus Rifan Zafarani² and Sapta Nugraha ${ }^{1, * *}$ \\ ${ }^{1}$ Department of Electrical Engineering, Faculty of Engineering, Universitas Maritim Raja Ali Haji \\ ${ }^{2}$ Department of Computer Science and Informatics, Faculty of Engineering, Universitas Maritim Raja Ali Haji \\ *Corresponding Author: saptanugraha@umrah.ac.id
}

\section{Article history}

Received: 18-01-2020

Revised: 14-03-2020

Accepted: 02-04-2020

DOI: $10.31629 /$ jit.v1i1.2134

\begin{abstract}
Malang Rapat is one of the villages which is located in the range of coastal region, Bintan regency, Riau islands Province. Most people in this village do not complete elementary level of education. Only a few graduates from Elementary School, Junior High School and Senior High School. The rate of education and its quality of human resources are very low. This condition is due to the monotonous system of teaching-learning process and lack of facilities and infrastructures. These are the problems that cause low quality of education. This research aims at developing teaching-learning process by applying Augmented Reality-Based Fun Book Technology (Round Table Learning Media) for Teaching-Learning of Coastal Community. This application is to develop knowledge by applying quizzes and games. The result obtained is that this technology is capable for handling the problems of low quality of education with its monotonous system of teaching-learning process.
\end{abstract}

Keywords: Coastal community, Fun Book technology, Augmented Reality

\section{Introduction}

Malang Rapat is one of the villages which is located in Gunung Kijang District, Bintan Regency, Riau islands Province. The area of Malang Rapat village covers approximately 771.225 hectares with the population of 1.829 persons of 548 households. Their livelihood is mostly fishermen (62\%), entrepreneurs and traders $(19 \%)$, farmers $(13 \%)$, and civil servants $(4,6 \%)$. The coastal region of Bintan Regency, Riau islands is a maritime area which becomes a priority of civil service. Hence, it goes along with one of the missions of Universitas Maritim Raja Ali Haji (UMRAH), which is, to develop knowledge and science, technology, art and culture through researches and innovative on the basis of maritime welfare. This area of study was chosen as the case study as, in the light of education, the level of education in this village is very low. Most people in Malang Rapat village do not complete their elementary school level/SD (856 persons). There are only 358 persons who completed elementary level, 201 persons who graduate from Junior High level, 130 persons who graduate from Senior High level. What is worse is that there are 77.186 kids who do not attend school [1].

Based on the data above, it indicates that the level of education and the quality of human 
resources seen from the light of education are very low. There are a number of factors that cause these conditions. Two of them are the monotonous system of teaching-learning process and the lack of facilities and infrastructures. Therefore, it is necessary that some breakthroughs and innovative be employed by involving the role of UMRAH through their missions of community service. This program is to foster any activities that develop teachinglearning process by applying audio-based Fun Book technology (round table learning media).

Fun book is a book system that takes advantage of barcode scan-based technology. Fun Book technology is a program development to generate learning product by combining Application and Game. This technology employs learning media as in the knowledge of Maritime Region of Riau islands for elementary school pupils on the basis of Augmented Reality and game. This innovation is a learning method aiming at boosting the knowledge of Riau islands. By doing so, it is expected that the students will have this maritime knowledge which is very important for them. Hence, this Fun Book technology is considered as Maritime Education Technology that will contribute and implemented in the development of maritime region in Tanjungpinang area [2].

\section{Library Research}

\subsection{Indonesia as a Maritime Country through Riau Islands}

According to statistic data issued by Directorate General of Public Administration and Ministry of Home Affairs in 2015, Indonesia is the biggest archipelago country in the world that has 17.504 islands, covering the land for 1.910.932,32 km2 and the sea for $3.273,810 \mathrm{~km} 2$. The total area of land and sea is $5.184,742 \mathrm{~km} 2$. The data also shows that one of the maritime regions in Indonesia which is quite larger than other regions is Riau islands, the 32th province of Republic Indonesia stipulated by House of Repetitive of Republic Indonesia (DPR RI) based on the Constitution (UUD) No. 25 with Tanjungpinang as its capital city. According to Health Office and Statistic Office of Riau islands, in 2016 Riau islands covers the area of 253.420 $\mathrm{km} 2$, which includes the sea covering $242.825 \mathrm{~km} 2$ (96\%) and the land covering 10.595,41 km2 (4\%). Riau islands has Regency of Bintan with Bintan Bunyu as its capital city, Regency of Karimun with
Tanjung Balai Karimun as its capital city, Regency of Natuna with Ranai as its capital city, Regency of Lingga with Daik as its capital city, Regency of Kota Tanjungpinang with Tanjungpinang as its capital city, Authority of Batam with Batam as its capital city, and Regency of Anambas with Tarempa as its capital city

\subsection{KPP Regulation}

The Ministry of Marine Affairs and Fisheries (KKP) ensures that islands are legally not for sale in Indonesia. This regulation is subject to any foreigners or even Indonesian individuals not to own islands in certain sites. It is stipulated in the Law No. 5 year 1960 on the Basic Regulation of Main Agrarian. The Director of Coastal Regions and Small Islands Empowerment from the Ministry of Marine Affairs and Fisheries stated that any foreigner is not allowed to purchase island to own privately. This also applies to Indonesian individuals. This regulation specifies more that any foreigner or Indonesian individuals is only given the usage right. This regulation is to avoid the problem as the spreading news in an internet site privateislandsonline.com advertising the selling of islands in Indonesia located in Ajab Bintan islands at Riau, Indonesia, for Rp 44 Million [3-4]

\subsection{Golden Generation as the Future Hope}

A scientific article on a research conducted by one of the lecturers of FKIP UNIKU argues in its title "The role of Education in Preparing Golden Generation". This scientific article discusses about the importance of Law No 20, year 2003 on National Education System proposing that the education system in Indonesia is expected to create the betterment of education quality and the students as well as future generation. The year of 2045 will be 100 years anniversary of Indonesian Independence. It suggests the productive age generation that is known as golden generation as we are supposed to celebrate the Golden Anniversary Indonesian Independence. It is hoped that this generation will show the cycle of national triumph in term of civilization. The role of teacher is not only teaching in the class, as explicitly stated in the Law No. 14 year 2005 on the role of teacher, but also being a professional educator who educates, teaches, guides, directs, trains, judges, and evaluates the students at the early ages through 
formal education from elementary to higher levels. Therefore, qualified education must be strived by the teachers since they themselves are the agents of change who act to create changes among students, so as to create religious, intellectual, qualified, productive, and comprehensive students in preparing to become golden generation 2045 .

\subsection{Character Building in Digital Era}

In a research conducted by Dini Palupi Putri, a college student of Institute Agama Islam Negeri (IAIN) Curup, which entitles "Character Building Education among Elementary School Students in Digital Era", she discusses the character building education as a process of implicating norms of life and religious values toward the students through knowledge and science, social and environmental values, and others. The development of social values on elementary school students has been very surprising. They have been familiar with digital life style as they always see around them. However, digital era does not only impact positively, but also negatively. Many researches have indicated that character building is formed along with repeated activities thus making it as a habit. This research is certain to base it on the concept that family, teachers, and members of society are expected to participate in guiding elementary school students in developing their frame of mind so as to take advantages of positive impacts from this habit. It is hoped that digital era will bring about good and positive things to build characters of nation, uniquely Indonesian

\subsection{Role of Learning Media as Children Education}

There is a research discussing on interactive learning media using education game. This research was conducted by Dwiyono, Department of Electronic Engineering Education, Faculty of Engineering, Universitas Negri Yogyakarta, which entitles, "The Development of Education Game as Interactive Learning Media on the Basic Competence by using hand tools and power tools ". This research makes use of model development ADDIE consisting of analysis, design, design, development, implementation, and evaluation. The result of this research is the development of main education game, level game, score, menu of materials, and arrangement. In its achievement, this game is categorized worthy as learning model that can be employed at the early ages [5]

\subsection{Children Ages in Using Technology Application}

Referring to Mansur in 2005, children age is the group of children who are uniquely still in the growing and developing process. They are undergoing a special growth and development process. They range between the age of 0-6 years old and 0-8 years old according to children education experts. This range of years is the golden age since they undergo the growth and development very fasy and irreplaceably in the future time. Based on various researches in the field of neurology, they show that $50 \%$ of children intellects are formed at the age of the first 4 years. After they reach the age of 8-10 years, their intellect development reach $80 \%$ and at the age of 18 years it reaches $100 \%[5,6]$.

\section{Method of Research}

\subsection{Method of Writing}

Method of writing in this research uses the combination of method of research, testing, and library research. Data used in this academic writing is primary and secondary ones. Primary data is sourced from research and testing, while secondary ones is obtained from library research.

\subsection{Location of Research}

The location of research and testing is in the Regency of Bintan, exactly in Elementary School/SDN 003 and SDN 006. The village of Gunung Kijang, Regency of Bintan is the location of survey and implementation of technology as it is also the location to obtain data and the effectivity of technology that we innovated.

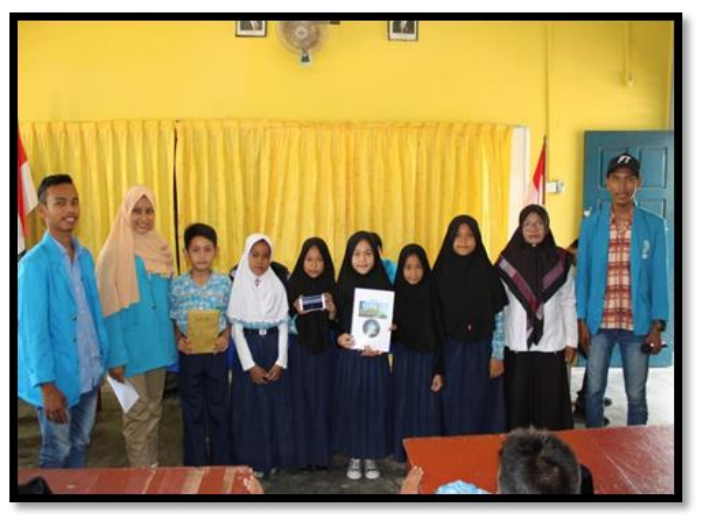

Figure 1. SDN 003 Gunung Kijang 


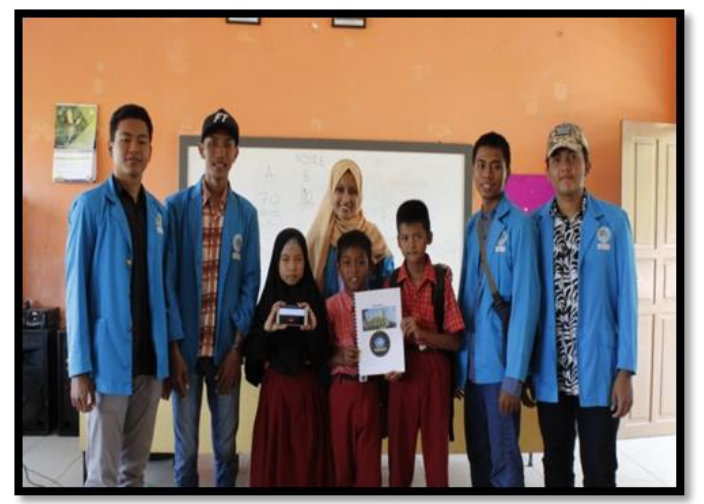

Figure 2. SDN 006 Gunung Kijang

\subsection{Method of Collecting Data}

Method of collecting data uses research and testing which is located in Bintan island. This source of data supports the innovation as the problem solving, while the testing was performed in those elementary schools located in Tanjungpinang city. The effective result of this innovation becomes the solution of the problem discussed.

\subsection{Concept of Tool}

The concept includes the diagram structure showing the process of making the tools in making a plan to be a creation. The following is the concept of tool supporting this innovation:

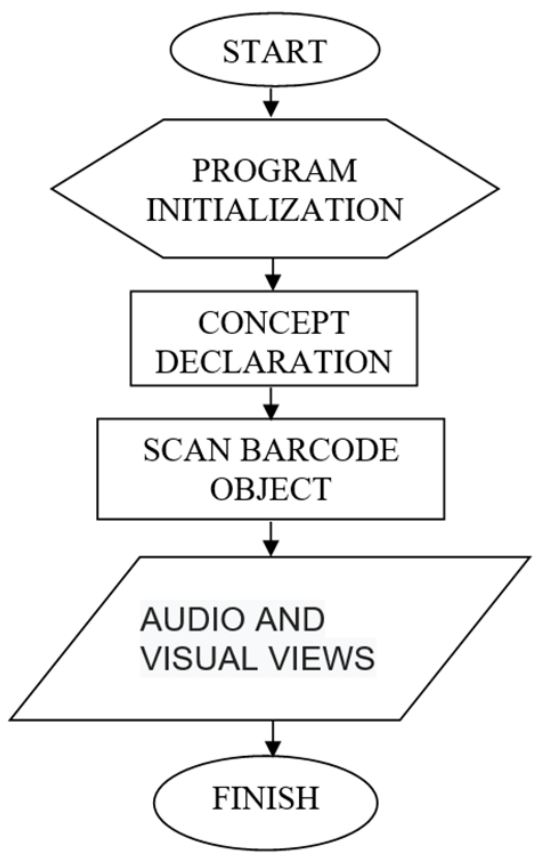

Figure 3. Frame of Research

\section{Discussion}

\subsection{Fun Book Technology}

After considering the problem above, Fun Book is the solution that is intended to develop the system of children's way of thinking so that their pattern of thinking is compatible with the method of education. The role of Fun Book as learning media is to combine the element of technology into an innovation. Hence, the effectiveness of previous and existing problems is possible to compare through some factors. The following is the specific explanations of how Fun Book really works and the result of testing that shows why it becomes an effective innovation and solution [7].

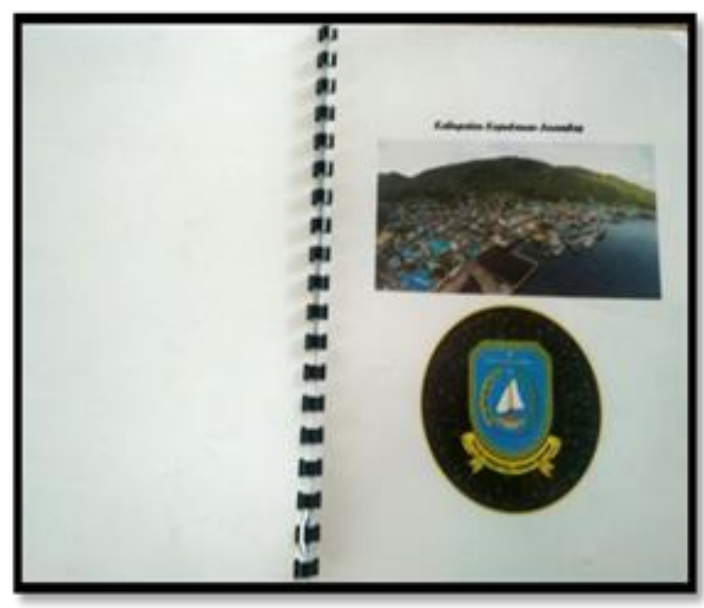

Figure 4. Fun Book Technology

\subsection{Specification of Fun Book Technology}

This Fun Book specification explains its divisions in technological elements. The following is specification elements of Fun Book technology:

1. System software or Android is the media which is a must in employing Fun Book innovation since Android plays main role in processing Fun Book as the medium and connector to the application system.

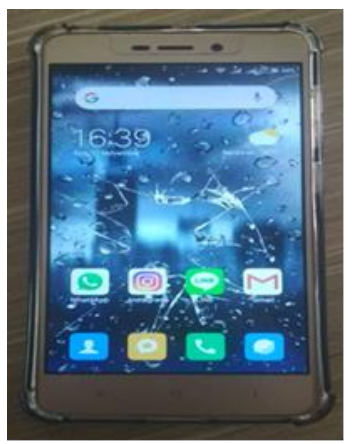

Figure 5. Display of Android HP 
2. AR (Augmented Reality) is one the applications that can be used in many beneficial functions. Augmented Reality play an important role in Fun Book since Augmented Reality is capable for offering learning materials that have been programmed to be applied as education media for children [8].

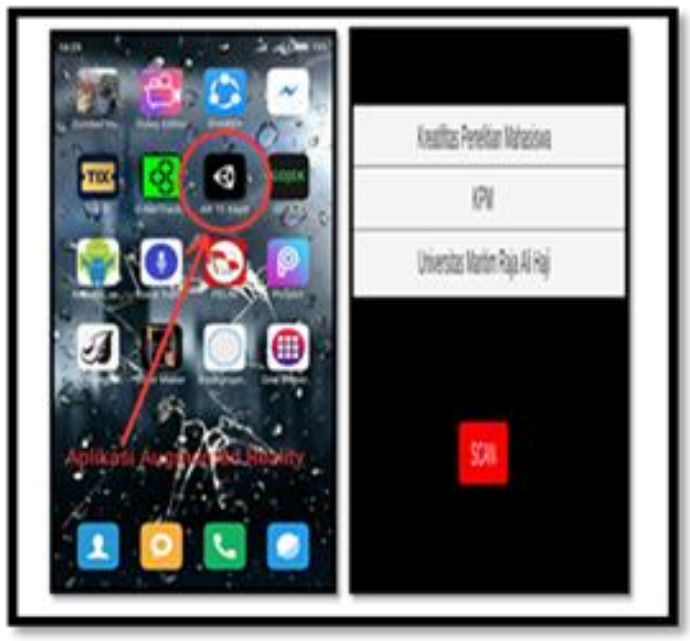

Figure 6. Augmented Reality Application

3. Books are the starting media to be used as media in this application. Both are combined as its working system is to scan a certain book as a learning book visual applied in this Fun Book innovation.

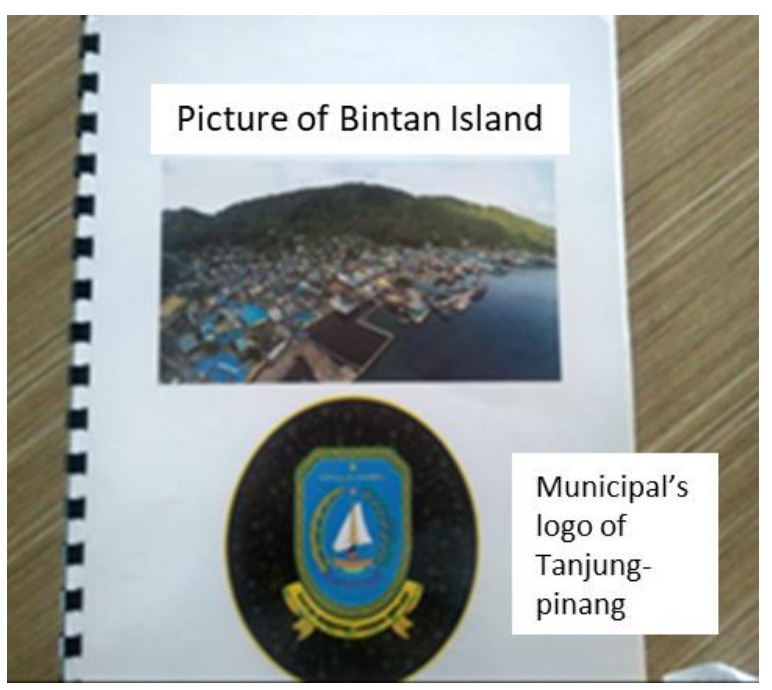

Figure 7. Fun Book

\subsection{Operation}

The operation of this innovation starts with introducing a certain book that already has a logo representing each Regency and the city in Riau islands. By doing so, those logos are programmed along with Augmented Reality application. Below is the figure how a book with its $\log 0$ starts the innovation of this Fun Book.

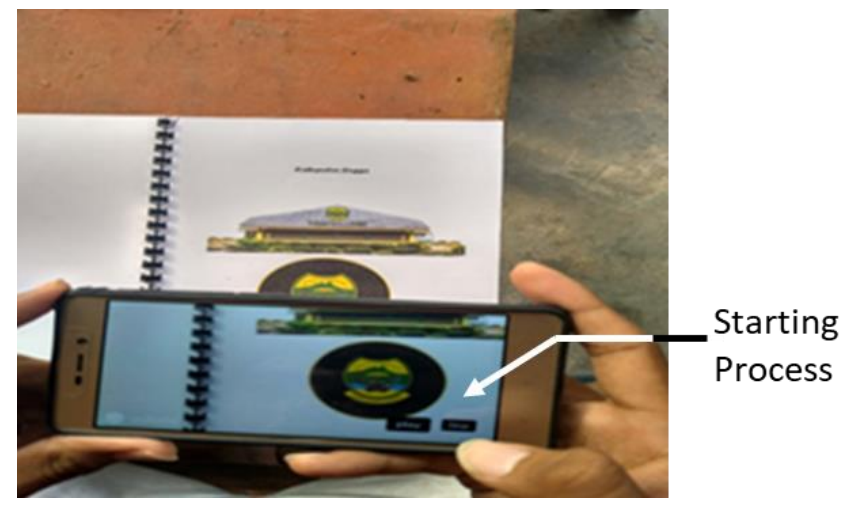

Figure 8. Starting operation of Fun Book

Then, if the logo has been scanned with AR application, there will show choices; Play and Stop. This menu will show because its barcode is sensitive as it is already programmed along with the application. After this step is done, there will show learning materials in the form of audio visual. It will show various explanations about the Regencies and the Cities in Riau islands. For example, there will show on the screen of the Android, that Bintan island has potential for attractive tourism and other related information.

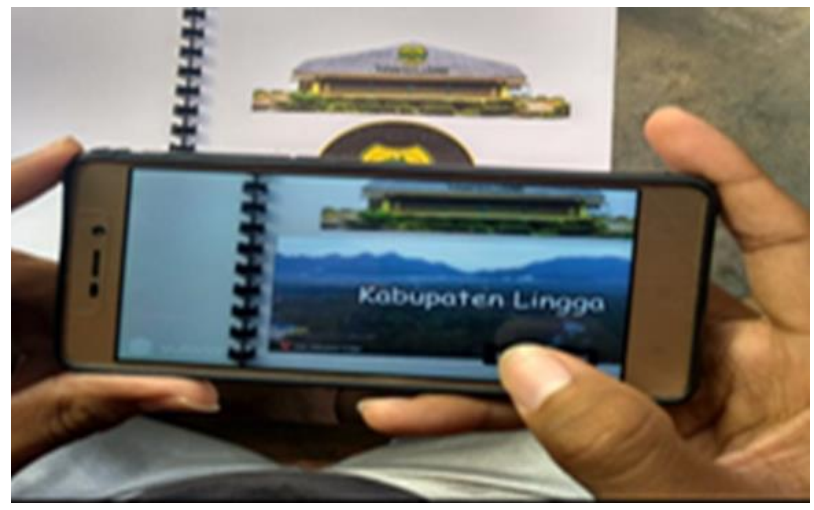

Figure 9. Augmented Reality Process

\subsection{Result of Testing}

The result of Fun Book testing has come to final phase, which is a phase when the users are ready to be used as education or learning media by elementary school students. The result of the testing also shows that Fun Book is a learning media that involves some activities, they are 
including the observation, hearing, thinking, and comprehending through technology. Therefore, this technology is suitable for elementary school students as their way of thinking are still very flexible to be trained from their early ages [9].

\subsection{Method of Adopting Fun Book Education}

Method of adopting Fun Book has some stages, which are; adopting with game, age adjustment, elementary school students, and explanation of Fun Book effectiveness as an innovation. As already well-known that Fun Book innovation is capable for becoming a solution of the problems in the coastal regions of Riau islands. This method is also the continuation of the testing and research that fully support this innovation as an effective solution.

\subsection{Method of Adopting Fun Book with Quiz Game}

Quiz Game is a supporting innovation in which it displays an application specifically designed for Fun Book innovation. This game has 2 main features, which are Play and Exit. Playing this game is just how to answer the problems provided in that Quiz Game application. The problems asked are everything about Fun Book innovation. Quiz Game has nominal time to think at each 10 main questions. The time given is 100 seconds. Each problem scores 10 and 100 for the whole points. Quiz Game is very influential in testing the effectiveness among elementary school students to memorize and comprehend Fun Book innovation and as an education media and a solution for helping student's intellectual, as concluded in somewhere else [10].
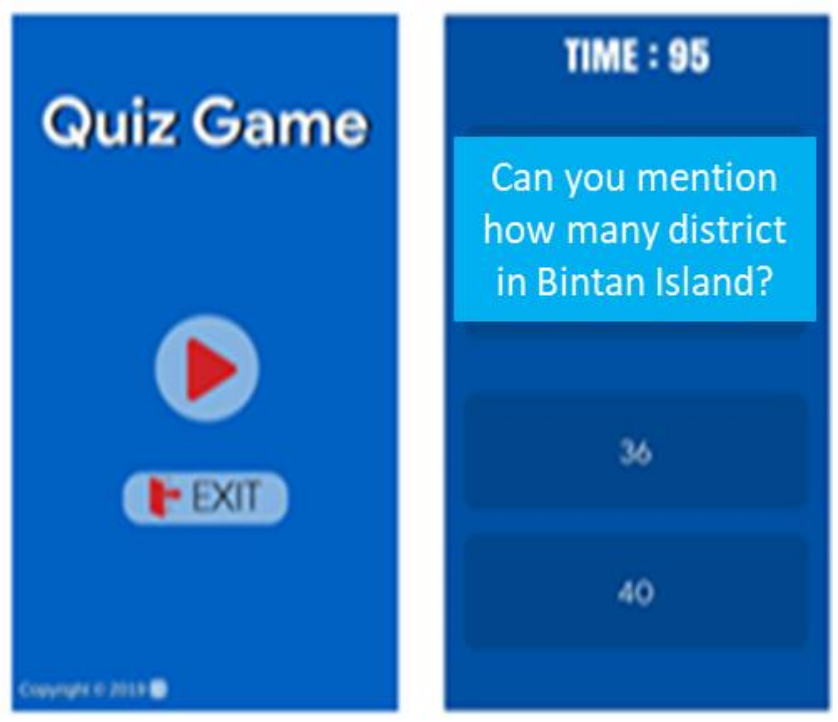

Figure 10. Quiz Game

\subsection{Adopting Fun Book through Age Adjustment}

Based on library research, the pattern of thinking among children has its own stages. One of them is the adoption of Fun Book innovation which is compulsory on the right target if we want to make it work effectively. The following is the graphic adjusted to adopt Fun Book innovation in this research.

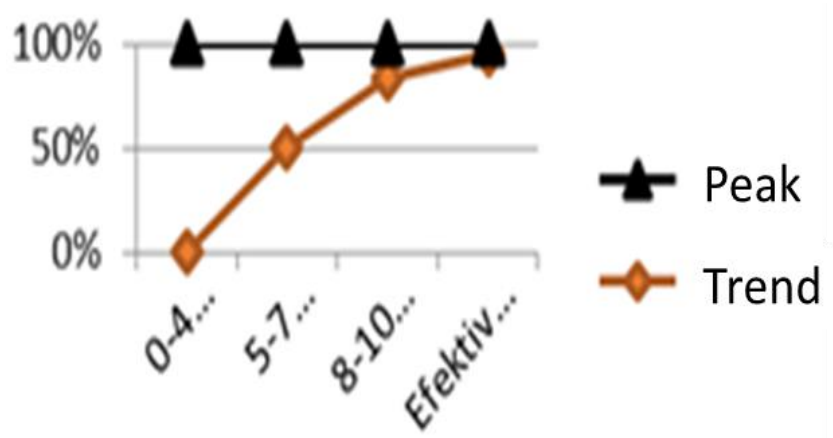

Figure 11. Graphic of Age Adjustment

According to researchers in the field of neurology, it is proven that $50 \%$ of the children intellects are formed at their first 4 years age. When they have reached 8-10 years old, their brain development reaches $80 \%$ and $100 \%$ at the age of 18 years old as presented by others [8-9]. Age adjustment for Fun Book is intended for children at 8-10 years old since this stage indicates their intellects reaching $80 \%$, in the sense that they are ready to get acquainted with a technology such as android. By adjusting age, it will be much easier to direct positive attitude and to land on the right target which is suitable with their pattern of thinking $[9,10]$.

\section{Conclusion}

Fun Book is an effective solution in handling the problems of literacy in coastal regions of Riau islands. The stage of solution that the writer conducted is a survey. The result of this research shows that Fun Book is innovated to be a learning material which is combined with Quiz Game. The method of adopting this innovation has resulted in effectiveness for 4 weeks as its significance can be seen on the peak of the graphic. This innovation also adopts age adjustment as suitable with the research and testing. The operation of this innovation uses Augmented Reality technology, barcode, and Quiz Game. 


\section{References}

[1] S. Nugraha dan A. Jabarriau, "Prototipe Sistem Monitoring Denyut Nadi Berbasis Wireless," J. Sustain. J. Has. Penelit. Dan Ind. Terap., vol. 5, no. 1, hlm. 26-30, Mei 2016.

[2] W. Dehua, L. Pan, L. Bo, and G. Zeng. 2012. Water Quality Automatic Monitoring System Based on GPRS Data Communications. Procedia Eng., vol. 28, hlm. 840-843.

[3] A. Mickelson and D. Tsvankin. 2017. Information Systems for Real-Time Water Quality Monitoring," dalam Encyclopedia of Sustainable Technologies, M. A. Abraham, Ed. Oxford: Elsevier, pp. 105-114.

[4] A. Maszczyk, A. Gołaś, P. Pietraszewski, R. Roczniok, A. Zając, and A. Stanula. 2014. Application of Neural and Regression Models in Sports Results Prediction. Procedia - Soc. Behav. Sci., vol. 117, pp. 482-487.

[5] R. R. Dhany, "RI Dibayangi Krisis Listrik, Masyarakat Masih Boros Energi," detikfinance. [Daring]. Soruce: https://finance.detik.com/energi/d2996701/ri-dibayangi-krisis-listrik-masyarakatmasih-boros-energi. [Accessed: 26-Mar-2018].
[6] T. Adiono, S. Fuada, A. P. Putra, dan Y. Aska. 2016. Desain Awal Analog Front-End Optical Transceiver untuk Aplikasi Visible Light Communication. J. Nas. Tek. Elektro Dan Teknol. Inf. JNTETI, vol. 5, no. 4, 2016.

[7] A. Martín-Garín, J. A. Millán-García, A. Baïri, J. Millán-Medel, and J. M. Sala-Lizarraga. 2018. Environmental monitoring system based on an Open Source Platform and the Internet of Things for a building energy retrofit. Autom. Constr., vol. 87, pp. 201-214.

[8] L. Parra, J. Rocher, J. Escrivá, and J. Lloret. 2018. Design and development of low-cost smart turbidity sensor for water quality monitoring in fish farms. Aquac. Eng., vol. 81, pp. 10-18.

[9] R. K. Pathria and P. D. Beale, Statistical Mechanics. Butterworth-Heinemann, 1996.

[10]S. Nugraha, A. E. Permanasari, dan I. Hidayah. 2013. Student Modeling Framework menggunakan Bayesian Network untuk Gaya Belajar VAK. Conference on Information Technology and Electrical Engineering (CITEE 2013), Yogyakarta, 2013, pp. 44-49. 